УДК 677.011

\title{
ИССЛЕДОВАНИЕ ВЛИЯНИЯ ЩЕЛОЧНОЙ ОБРАБОТКИ НА СОСТАВ И СВОЙСТВА ЭЛЕМЕНТАРИЗОВАННОГО ЛЬНЯНОГО ВОЛОКНА
}

\author{
(C) В.Г. Стокозенко ${ }^{l^{*}}$, А.П. Морыганов ${ }^{1}$, И.Ю. Ларин ${ }^{2}$, Е.Р. Воронина ${ }^{2}$ \\ ${ }^{1}$ Институт химии растворов им. Г.А. Крестова РАН, ул. Академическая, 1, \\ Иваново, 153045 (Россия), e-mailvgs@isc-ras.ru \\ ${ }^{2}$ Ивановский государственный политехнический университет, \\ Шереметевский пр., 21, Иваново, 153000 (Россия)
}

\begin{abstract}
Обоснована возможность модифицирования льняного волокна по принципиально новой технологической схеме, включающей целенаправленное разрушение соединительных тканей действием циклических деформирующих нагрузок (элементаризация) с последующей химической обработкой. Анализ свойств полученных элементарных волокон природного происхождения показал, что по геометрическим показателям элементарные волокна льна близки к волокнам хлопка и шерсти, а по прочности значительно их превосходят, что открывает перспективы создания на их основе инновационных изделий технического, текстильного и медицинского назначения. Исследовано влияние химических обработок, моделирующих процессы модификации и облагораживания льноматериалов, на состав основных примесей и свойства элементаризованных волокон. Показано, что высокая степень очистки элементаризованного волокна повышает возможность деструкции целлюлозы. Проведен подбор химических реагентов и концентрационно-временных параметров процесса, обеспечивающих оптимальную степень очистки элементаризованного волокна без разрушения его целлюлозной составляющей. Установлено, что химические обработки элементаризованного льноволокна по сравнению с котонизированным должны проводиться в более мягких условиях: концентрация щелочи - до 2 г/л, длительность процесса - до 60 мин. В качестве щелочного реагента могут применяться более слабые, чем гидроксид натрия, основания, в частности карбонат натрия. Незначительная деструкция целлюлозы, отмечаемая при последующем воздействии окислителя, подтверждается малым содержанием в ней карбоксильных и альдегидных групп, а также прочностными показателями нового вида волокон: прочность волокон до и после химических обработок не имеет значимых отличий и находится в пределах 40,4-42,0 cH/текс.

Ключевые слова: элементаризованное льноволокно, котонизированное льноволокно, лигноуглеводный комплекс, лигнин, пектины, гемицеллюлозы, целлюлоза.
\end{abstract}

Работа выполнена при финансовой поддержке гранта РФФИ (проект № 15-48-03021).

\section{Введение}

В настоящее время модифицирование льноволокна осуществляется путем механического разрушения структуры комплексных волокон в продольном направлении и укорочения (так называемой котонизации). Результатом таких воздействий является получение волокнистой массы, включающей как элементарные волокна, так и тонкие комплексные пучки. Общим недостатком котонизированных волокон, делающим проблематичной их дальнейшую переработку по существующим технологиям хлопко- и шерстепрядения, является высокая дисперсность по геометрическим размерам, физико-механическим показателям,

Стокозенко Валерия Германовна - кандидат технических наук, старший научный сотрудник, e-mail: vgs@isc-ras.ru

Морыганов Андрей Павлович - доктор технических наук, профессор, заведующий лабораторией,

e-mail:apm@isc-ras.ru

Ларин Игорь Юрьевич - кандидат технических наук, доцент, e-mail: larin_igor@inbox.ru

Воронина Елена Руфимиовна - кандидат технических наук, доцент, e-mail: larin_igor@inbox.ru химическому составу и наличию примесей (остатки костры, пыль), а также волокон с высокой степенью одревеснения.

Вместе с тем анализ свойств единичных элементарных волокон природного происхождения (льняного, хлопкового, шерстяного) показывает, что по линейной плотности и толщине элементарные волокна льна близки к волокнам хлопка и шерсти, а по

\footnotetext{
* Автор, с которым следует вести переписку.
} 
прочности значительно превосходят их (табл. 1). Это дает основание прогнозировать возможность как адаптации льняных волокон к их совместной переработке с хлопковыми и шерстяными по классическим системам прядения, так и выработки чистольняных пряж.

Новым направлением в модификации льняных волокон, позволяющим в максимальной степени рационально использовать ценное отечественное сырье, является разрабатываемый в настоящее время способ элементаризации комплексных лубяных волокон. Подход к решению задачи основан на целенаправленном разрушении соединительных тканей на специальном устройстве под действием многократных циклических деформирующих нагрузок, обеспечивающих чередование операций «нагрузка - разгрузка - частичная релаксация» [4]. При этом достигается полное разделение волокнистого пучка на отдельные составляющие его элементарные волокна, очистка их от неразработанных волокон, частиц костры, пыли и распределение на фракции волокон по длине.

Проведенными исследованиями было установлено, что такой подход обеспечивает получение однородного по физико-механическим и геометрическим показателям высокоочищенного волокна (с линейной плотностью, близкой показателям хлопкового волокна) и фракционированием его по группам длин (от 7,5 до 50 мм) [5]. Волокна с длиной 20-50 мм могут быть переработаны в высококачественную пряжу средних и высоких линейных плотностей; другие фракции элементаризованного волокна применимы для производства медицинской продукции, средств личной гигиены, нетканых материалов, а также целлюлозы, ее эфиров и изделий на их основе.

Основная часть элементаризованных льноволокон будет подвергаться химическим обработкам: текстильные материалы на их основе - облагораживанию, колорированию и заключительной отделке; медицинские изделия - отбеливанию (с возможностью нанесения лекарственных препаратов); получение целлюлозы предусматривает варку и отбелевание. В связи с этим необходимо исследовать поведение модифицированного льноволокна и сопутствующих примесей в условиях, моделирующих основные процессы химических обработок. На данном этапе работы нами оценивалось влияние природы щелочного реагента и его концентрации на состояние лигноуглеводного комплекса элементаризованного льноволокна.

Таблица 1. Сравнительные характеристики волокон [1-3]

\begin{tabular}{l|c|c|c}
\hline \multicolumn{1}{c|}{ Наименование показателя } & $\begin{array}{c}\text { Элементарное } \\
\text { волокно льна }\end{array}$ & $\begin{array}{c}\text { Хлопковое } \\
\text { волокно }\end{array}$ & $\begin{array}{c}\text { Шерсть однородная тонкая для кам- } \\
\text { вольного прядения }\end{array}$ \\
\hline Линейная плотность, мтекс & $125-330$ & $100-185$ & - \\
Размер поперечного сечения, мкм & $12,0-23,0$ & $10-25$ & $14,5-23,0$ \\
Удельная разрывная нагрузка, сН/текс & $24-80$ & $21-34$ & 14 \\
Длина, мм & $1,0-120,0$ & $7,5-55,0$ & $5,0-120,0$ \\
\hline
\end{tabular}

\section{Экспериментальная часть}

Объектами исследования служили техническое льняное волокно и полученные из него методом многократных циклических деформирующих нагрузок образцы элементаризованных волокон. В качестве образцов сравнения применяли льноволокно, котонизированное по технологии ф. Темафа (продольное разволокнение на кардочесальном оборудовании).

Волокна подвергали щелочной обработке и отбеливанию в среде пероксида водорода по разработанным в ИХР РАН методам [6]. В качестве щелочных реагентов использовали гидроксид натрия и карбонат натрия (ч.д.а.) в концентрации 1-5 г/л. Соотношение между объемом раствора и массой волокнистого материала составляло $50: 1$. Длительность обработки в изотермических условиях при температуре $100 \pm 0,5^{\circ} \mathrm{C}$ составляла 20-120 мин.

Для предохранения целлюлозы от деструктирующего влияния кислорода в щелочной среде в систему вводили восстановитель - триэтаноламин (1,0 г/л) [6]. Определение количества остаточной щелочи при отварке лубяных волокон проводили путем кислотно-основного титрования водных вытяжек из отваренных образцов по методике, указанной в [7].

У исходных и обработанных волокон определяли содержание целлюлозы (по гидролитически-весовому методу [8]), пектинов (в виде соли кальция полигалактуроновой кислоты [8]), лигнина (по сернокислотному методу [9]), гемицеллюлоз (в щелочном фильтрате после определения $\alpha$ - целлюлозы путем окисления фильтрата раствором бихромата калия [10]), показатели степени окисления целлюлозы (медное число и содержание альдегидных и карбоксильных групп) [9], прочностные показатели (разрывную нагрузку) [3]. 


\section{Обсуждение результатов}

Прилагаемые к комплексному волокну циклические деформирующие нагрузки вызывают нарушение целостности соединительных тканей и частичное удаление их из волокна, что значительно эффективнее применяемого в классической технологии котонизации продольного разволокнения путем прочеса. По данным таблицы 2 механическое воздействие сопровождается удалением лигнина (до 50\%) и пектинов (до 34\%) с одновременным повышением содержания целлюлозной составляющей (до 80,1\%). Итогом этого становится резкое увеличение границы раздела фаз, на которой при дальнейших химических обработках протекают гетерогенные процессы взаимодействия реагентов с примесями, сопровождающиеся их растворением.

Динамика удаления примесей из льняного волокна в процессах щелочных обработок (рис.) убедительно подтверждает эти аргументы. Высокая степень элементаризации комплексного волокна обеспечивает резкий рост скорости растворения примесей под действием щелочных агентов. Например, под воздействием гидроксида натрия потеря 10\% массы элементаризованного волокна происходит за 30 мин, при обработке котонизированного льноволокна такие результаты достигаются лишь через 60 мин, т.е. в 2 раза медленнее.

Обращает на себя внимание существенное различие в потере массы (одного из основных показателей, применяемых при контроле качества подготовки полуфабрикатов из льноволокна) изучаемых волокон, прошедших обработку в присутствии гидроксида и карбоната натрия.

Элементаризованное волокно, лишенное значительной части примесей, защищающих целлюлозу от деструктирующего действия химических реагентов, в большей степени, чем котонизированное, подвергается риску разрушения в агрессивных средах. При двухчасовой обработке раствором гидроксида натрия оно теряет до 1/5 своей первоначальной массы, что явно указывает на развитие химических трансформаций в целлюлозной составляющей, неизбежно приводящих к ухудшению прочностных свойств волокон. В случае карбоната натрия этот эффект значительно менее выражен и возможность повреждения волокна незначительна.

Учитывая меньшее, по сравнению с котонизированным, содержание примесей в элементаризованном волокне, можно предположить возможность использования при его химических обработках карбоната натрия.

Для обоснования выбора щелочного реагента и определения его оптимальной концентрации при химических обработках элементаризованных волокон было проведено исследование изменения содержания гидроксида и карбоната натрия в растворе (табл. 3) в совокупности с изменением степени растворения основных примесей (табл. 4).

Таблица 2. Влияние вида обработки на состав льняного волокна

\begin{tabular}{l|c|c|c|c|c}
\hline \multicolumn{1}{c|}{ Вид льноволокон } & Потеря & \multicolumn{3}{|c}{ Остаточное содержание, \% } \\
\cline { 3 - 6 } & массы, \% & целлюлозы & лигнина & пектинов & гемицеллюлоз \\
\hline Исходное & - & 64,4 & 5,1 & 4,8 & 10,5 \\
Котонизированное & - & 76,2 & 4,8 & 4,2 & 10,2 \\
$\begin{array}{l}\text { Котонизированное, подвергнутое химической } \\
\text { обработке в среде гидроксида натрия* }\end{array}$ & 10,7 & 80,4 & 3,1 & 3,3 & 4,7 \\
$\begin{array}{l}\text { Котонизированное, подвергнутое химической } \\
\text { обработке в среде карбоната натрия* }\end{array}$ & 8,5 & 81,4 & 3,9 & 3,8 & 5,6 \\
$\begin{array}{l}\text { Элементаризованное } \\
\text { Элементаризованное, подвергнутое химической }\end{array}$ & - & 80,1 & 2,6 & 3,2 & 9,8 \\
$\begin{array}{l}\text { обработке в среде гидроксида натрия* } \\
\text { Элементаризованное, подвергнутое химической } \\
\text { обработке в среде карбоната натрия* }\end{array}$ & 19,1 & 84,7 & 1,8 & 2,1 & 2,8 \\
\hline
\end{tabular}

*Варка при $100{ }^{\circ} \mathrm{C}$ в течение 2 ч в растворах, содержащих, г/л: щелочной реагент -5, ТЭА $-1,0$, комплексон $-0,1$.

Таблица 3. Изменение остаточного содержания щелочных реагентов в растворах (в пересчете на гидроксид натрия) в процессе обработки элементаризованного льноволокна

\begin{tabular}{c|c|c|c|c|c|c|c|c}
\hline & \multicolumn{9}{|c}{ Щелочной реагент } \\
\cline { 2 - 9 } Длительность & \multicolumn{7}{|c|}{ Гидроксид натрия } & \multicolumn{5}{c}{ Концентрация, г/л } \\
\cline { 2 - 9 } обработки, мин натрия \\
\cline { 2 - 9 } & 1,0 & 2,0 & 3,0 & 5,0 & 1,0 & 2,0 & 3,0 & 5,0 \\
\hline 30 & 0,31 & 1,06 & 1,76 & 1,81 & 0,47 & 1,18 & 2,02 & 2,52 \\
60 & 0,21 & 0,78 & 1,02 & 1,00 & 0,28 & 0,82 & 1,14 & 1,25 \\
120 & 0,10 & 0,21 & 0,28 & 0,41 & 0,13 & 0,26 & 0,32 & 0,48 \\
\hline
\end{tabular}




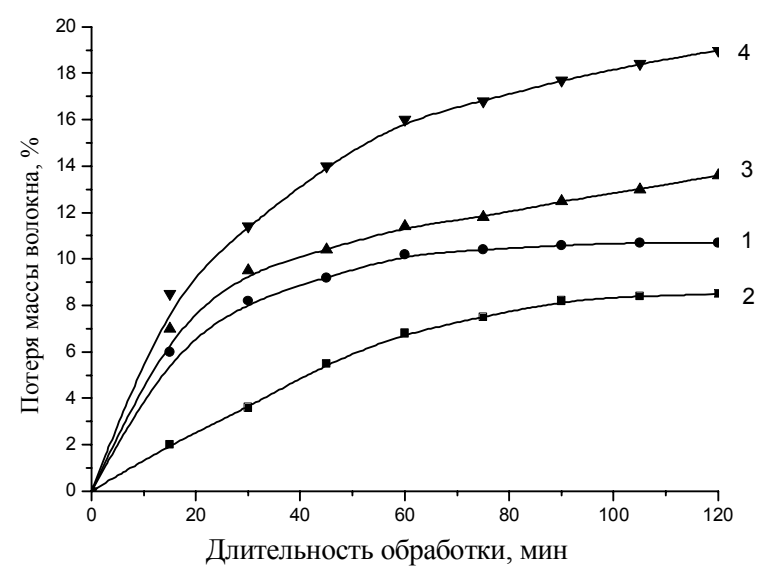

Влияние вида предварительной механической обработки и природы щелочного реагента на потерю массы льняных волокон:

1, 2 - котонизированного,

3, 4 - элементаризованного;

обработка в среде: 1, 4 - гидроксида натрия, 2, 3 - карбоната натрия

Таблица 4. Изменение содержания основных примесей элементаризованного льноволокна после щелочных обработок (длительность обработки - 120 мин)

\begin{tabular}{c|c|c|c}
\hline \multirow{2}{*}{ Примеси } & $\begin{array}{c}\text { Концентрация щелочного } \\
\text { реагента, г/л }\end{array}$ & \multicolumn{2}{|c}{$\begin{array}{c}\text { Остаточное содержание примесей в волокне, \%, } \\
\text { при обработке в растворе }\end{array}$} \\
\cline { 2 - 3 } & До обработки & гидроксида натрия & карбоната натрия \\
\hline \multirow{3}{*}{ Лигнин } & 2 & 2,6 & 2,6 \\
& 3 & 2,3 & 2,3 \\
& 5 & 2,0 & 3,8 \\
\hline \multirow{3}{*}{ Пектины } & До обработки & 3,8 & 3,1 \\
& 2 & 3,2 & 2,8 \\
\hline \multirow{3}{*}{ Гемицеллюлозы } & 3 & 2,6 & 2,3 \\
\hline & 5 & 2,1 & 9,8 \\
\hline
\end{tabular}

Динамика выбирания волокном щелочей из растворов показывает, что в течение 2 ч их содержание снижается до 0,1-0,5 г/л, т.е. практически все они сорбируются волокном и связываются примесями. Абсолютные значения остаточного содержания основных примесей льноволокна, обработанного в среде исследуемых щелочных реагентов, практически идентичны. Дальнейшее снижение содержания основных примесей в волокне нецелесообразно, т.к. может повлечь за собой ухудшение его физико-механических свойств.

Таким образом, щелочная обработка элементаризованного льноволокна может проводиться в значительно более мягких по сравнению с котонизированным волокном концентрационно-временных условиях: концентрация щелочи - не более 2 г/л, длительность процесса - до 60 мин. В этих условиях не наблюдается гидролитическая деструкция целлюлозы, что подтверждается значением медного числа 0,08 (отсутствию деструкционных повреждений целлюлозы соответствуют значения медного числа 0,1-0,2) [10]. Это подтверждается и результатами экспериментальных исследований прочностных показателей нового вида волокон: показатели прочности волокон до и после химических обработок не имеют значимых отличий и находятся в пределах 40,4-42,0 cH/текс.

При применении более концентрированных растворов значение медного числа возрастает до 0,22-0,25, что свидетельствует об активации в целлюлозе гидролитических процессов и возникновении риска химического повреждения волокна.

Представляет интерес исследование изменения количества функциональных групп, характеризующих присутствие окисленной формы целлюлозы - оксицеллюлозы - как косвенного показателя деструкционных процессов при окислительном отбеливании элементаризованного льноволокна (табл. 5). Полученные данные показывает, что на стадии окисления при малых концентрациях щелочных агентов содержание альдегидных групп практически постоянно, а содержание карбоксильных групп не превышает показатель, характеризующий начало глубоких окислительных процессов (по данным [10] суммарное количество этих групп должно быть не менее $0,34 \%$ ). Активация окислительных превращений наблюдается только при отбеливании волокна, предварительно обработанного в растворе с повышенным до 5 г/л содержанием гидроксида натрия. 
Таблица 5. Изменение содержания карбоксильных групп в целлюлозе элементаризованного льняного волокна при отбеливании в среде пероксида водорода

\begin{tabular}{|c|c|c|}
\hline Вид обработки & $\begin{array}{c}\text { Количество карбоксиль- } \\
\text { ных групп, \% }\end{array}$ & $\begin{array}{c}\text { Количество альдегидных } \\
\text { групп, \% }\end{array}$ \\
\hline $\begin{array}{l}\text { Обработка в растворе гидроксида натрия (1,5 г/л), } 60 \text { мин; } \\
\text { отбеливание в среде пероксида водорода (3 г/л), } 60 \text { мин; pH } 10\end{array}$ & 0,12 & 0,023 \\
\hline $\begin{array}{l}\text { Обработка в среде карбоната натрия (1,5 г/л), } 60 \text { мин; } \\
\text { отбеливание в среде пероксида водорода (3 г/л), } 60 \text { мин; pH } 10\end{array}$ & 0,11 & 0,023 \\
\hline $\begin{array}{l}\text { Обработка в растворе гидроксида натрия (5 г/л), } 120 \text { мин; } \\
\text { отбеливание в среде пероксида водорода (3 г/л), } 60 \text { мин; рН } 10\end{array}$ & 0,28 & 0,052 \\
\hline
\end{tabular}

Таким образом, при выборе условий химических обработок льняного волокна (или изделий на его основе), элементаризованного по новому способу, необходимо учитывать повышенную восприимчивость целлюлозной составляющей к концентрационно-временным параметрам.

\section{Bblводbl}

1. Показано, что разрабатываемый способ элементаризации льняных волокон вызывает механическое удаление значительной части примесей (лигнина до 50\% и пектинов до 34\%) с одновременным повышением содержания целлюлозной составляющей (до 80,1\%), что резко увеличивает границы раздела фаз, на которой при дальнейших химических обработках протекают гетерогенные процессы деструкции и растворения оставшейся части примесей. Высокая степень очистки волокна при механических обработках повышает риск деструкции целлюлозы при воздействии химических реагентов.

2. На основании исследования динамики удаления из льняных волокон основных примесей при комбинировании процессов механической элементаризации и варки в присутствии щелочных реагентов различной природы и концентрации обоснованы условия химических обработок, обеспечивающие оптимальную степень очистки элементаризованного волокна без разрушения его целлюлозной составляющей.

\section{Список литературь}

1. Справочник по хлопкопрядению / под ред. Б.П. Широкова и др. М., 1985. 473 с.

2. Прядение льна и химических волокон : справочник / под ред. Л.Б. Карякина, Л.Н. Гинзбурга. М., 1991. 544 с.

3. Кукин Г.Н., Соловьев А.Н., Кобляков А.Н. Текстильное материаловедение (волокна и нити) : учебник для ву3ов. М., 1989. $352 \mathrm{c.}$

4. Патент № 2497982 (РФ). Способ обработки комплексных лубяных волокон и устройство для его реализации / И.Ю. Ларин, Е.Р. Савинов / 2013.

5. Ларин И.Ю., Воронина Е.Р., Стокозенко В.Г., Морыганов А.П. Новый подход к модификации лубяных волокон // Сборник материалов XIX Международного научно-практического форума «Физика волокнистых материалов: структура, свойства, наукоемкие технологии и материалы («SMARTEX-2016»)». Иваново, 2016. C. 206-210.

6. Губина С.М., Стокозенко В.Г. Теоретические и технологические аспекты химической котонизации // Текстильная промышленность : научный альманах. 2006. № 1. С. 18-20.

7. Отделка хлопчатобумажных тканей : справочник / под ред. Б.Н. Мельникова. Иваново, 2003. 484 с.

8. Оболенская А.В., Ельницкая 3.П., Леонович А.А. Лабораторные работы по химии древесины и целлюлозы : учебное пособие для вузов. М., 1991. 320 с.

9. Хабаров Ю.Б., Песьякова Л.А. Аналитическая химия лигнина. Архангельск, 2008. 172 с.

10. Садов Ф.И., Соколова Н.М., Вильдт Е.О. Лабораторный практикум по курсу «Химическая технология волокнистых материалов». М., 1963. 428 с.

11. Иванов В.И., Каверзнева Е.Д., Кузнецова 3.И. Химические превращения макромолекул целлюлозы под влиянием окислителей // Известия АН СССР. 1953. № 2. С. 374-384.

Поступило в редакцию 20 октября 2016 г. 
Stokozenko V.G. ${ }^{l}$, Moryganov A.P. ${ }^{l}$, Larin I.Yu. ${ }^{2}$, Voronina E.R. ${ }^{2}$ RESEARCH OF INFLUENCE OF ALKALINE HANDLING ON STRUCTURE AND ELEMENTARIZOVANNY PROPERTIES LINEN FIBRE

${ }^{1}$ Institute of Solution Chemistry of G. A. Krestov of the Russian Academy of Sciences, ul. Akademicheskaya, 1, Ivanovo, 153045 (Russia),e-mail:vgs@isc-ras.ru

${ }^{2}$ Ivanovo state polytechnical university, pr. Sheremetevsky, 21, Ivanovo, 153000 (Russia)

The possibility of modification of linen fibers according to the essentially new technological scheme which includes purposeful destruction of connective tissues by the action of cyclic de-forming loads (elementarization) with the subsequent chemical processing is proved. The analysis of properties of the obtained elementary fibers of natural origin has shown that geometrical indicators of flax elementary fibers are close to the ones of cotton and wool fibers, and their du-rability is considerably higher, that gives the prospects to create innovative products for technical, textile and medical purposes on their basis. The influence of chemical processings, modeling the processes of modification and upgrading of flax materials, on the composition of basic admixtures and properties of elementarized fibers is investigated. It is shown that the high extent of purification of elementarized fibers raises the possibility of cellulose destruction. The selection of chemical reagents and concentration and time parameters of the process, which provide the optimum extent of purification of elementarized fibers without the destruction of its cellulose component, is carried out. It is determined that chemical processings of elementarized flax fibers in comparison with the cottonized ones have to be carried out in softer conditions: the concen-tration of alkali - to $2 \mathrm{~g} / \mathrm{l}$, the processing duration - up to $60 \mathrm{~min}$. As the alkaline reagent the bases weaker than sodium hydroxide can be applied, in particular, sodium carbonate. The insig-nificant destruction of cellulose noted during the subsequent influence of an oxidizer is confirmed by small contents of carboxyl and aldehyde groups in it and also by the durability indexes of new type of fibers: the durability of fibers before and after the chemical processings has no significant differences and is within the limits 40,4-42,0 sn/tex.

Keywords: elementarizovanny flax fiber, kotonizirovanny flax fiber, lignougelodny complex, lignin, pectins, gemitsellyuloza, cellulose.

\section{References}

1. Spravochnik po khlopkopriadeniiu [Cotton Handicraft Handbook], ed. B.P. Shirokov i dr. Moscow, 1985, 473 p. (in Russ.).

2. Priadenie l'na i khimicheskikh volokon: Spravochnik [Spinning of flax and chemical fibers: Handbook], ed. L.B. Kariakin, L.N. Ginzburg. Moscow, 1991, 544 p. (in Russ.).

3. Kukin G.N., Solov'ev A.N., Kobliakov A.N. Tekstil'noe materialovedenie (volokna i niti): Uchebnik dlia vuzov. [Textile materials science (fibers and threads): Textbook for high schools]. Mosocw, 1989, 352 p. (in Russ.).

4. Patent 2497982 (RU). 2013. (in Russ.).

5. Larin I.Iu., Voronina E.R., Stokozenko V.G., Moryganov A.P. Sbornik materialov XIX Mezhdunarodnogo nauchnoprakticheskogo foruma «Fizika voloknistykh materialov: struktura, svoistva, naukoemkie tekhnologii $i$ materialy («SMARTEX-2016»)». [Collection of materials of the XIX International Scientific and Practical Forum "Fibrous materials physics: structure, properties, science-intensive technologies and materials (SMARTEX-2016)"]. Ivanovo, 2016, pp. 206-210. (in Russ.).

6. Gubina S.M., Stokozenko V.G. Tekstil'naia promyshlennost'. Nauchnyi al'manakh, 2006, no. 1, pp. 18-20. (in Russ.).

7. Otdelka khlopchatobumazhnykh tkanei: Spravochnik [Finishing of cotton fabrics: Handbook], ed. B.N. Mel'nikov, Ivanovo, 2003. 484 p. (in Russ.).

8. Obolenskaia A.V., El'nitskaia Z.P., Leonovich A.A. Laboratornye raboty po khimii drevesiny $i$ tselliulozy: Uchebnoe posobie dlia vuzov. [Laboratory work on chemistry of wood and cellulose: Textbook for high schools]. Moscow, 1991, 320 p. (in Russ.).

9. Khabarov Iu.B., Pes'iakova L.A. Analiticheskaia khimiia lignina. [Analytical chemistry of lignin]. Arkhangel'sk, 2008, 172 p. (in Russ.).

10. Sadov F.I., Sokolova N.M., Vil'dt E.O. Laboratornyi praktikum po kursu «Khimicheskaia tekhnologiia voloknistykh materialov». [Laboratory workshop on the course "Chemical technology of fibrous materials"]. Moscow, 1963, 428 p. (in Russ.).

11. Ivanov V.I., Kaverzneva E.D., Kuznetsova Z.I. Izvestiia AN SSSR, 1953, no. 2, pp. 374-384. (in Russ.).

Received October 20, 2016

Revised December 7, 2016

\footnotetext{
* Corresponding author.
} 